\title{
Sciendo
}

\author{
Research Article \\ (C) 2019 Sandro Serpa and Carlos Miguel Ferreira. \\ This is an open access article licensed under the Creative Commons \\ Attribution-NonCommercial-NoDerivs License \\ (http://creativecommons.org/licenses/by-nc-nd/3.0/)
}

\section{Sociology as Scientific Knowledge}

\author{
Sandro Serpa \\ Department of Sociology, Faculty of Social and Human Sciences, \\ University of the Azores, Portugal; \\ Interdisciplinary Centre of Social Sciences - CICS.UAc/ CICS.NOVA.UAc, \\ Interdisciplinary Centre for Childhood and Adolescence - NICA - UAC \\ Carlos Miguel Ferreira \\ Interdisciplinary Centre of Social Sciences-CICS.NOVA
}

Doi: 10.2478/jesr-2019-0035

\begin{abstract}
Sociology is a science with specificities and which can potentially offer a more rigorous knowledge about reality. The goal of this position paper is, by means of a thorough literature review, to contribute to demonstrating the urgency of using a sociological stance in a more complete understanding of the social, as well as of Sociology itself as a science. It is concluded that Sociology, a multi-paradigmatic science, seeks to articulate macro-social dynamics with local processes, allowing to connect the subjective significances with the practices, and which focus on the articulations between systems and actors, between structures and practices, between the reality of the social conditions of existence, and the social construction of reality. As an implication, Sociology as a scientific representation and practice of the social, can be cumbersome by helping to dismantle commonly shared preconceived ideas about the instituted social order.
\end{abstract}

Keywords: sociology, scientific knowledge, science, research

\section{Introduction}

In today's world, obtaining knowledge is critical in a context of the weakening of the classic frameworks of several of the socialisation institutions (Torres, 2016; Lellouche, 2009).

As a science, Sociology (whether in its introductory or general dimension, or in the form of specialised sociologies) is acknowledged in the scientific field as a scientific discipline that envisages in its specific way social reality, producing plural theoretical topics, formulating research problems in the context of these topics and developing methodical strategies that gear empirical research (Ferreira \& Serpa, 2017).

Specifically, Sociology is a science that has specificities, namely being pluriparadigmatic (Au, 2018; Kurawa, 2012; Condorelli, 2018; Zougris, 2018), and which can potentially unravel a deeper knowledge about the relationship between social factors and scientific knowledge (Bourdieu, 2013):

In fact, the confirmation of sociological dynamics that are internal to the scientific field, perhaps extended to the rationality that scientists lend to their gestures, and the explanation or denunciation of interests that are strange to the truth, in the same domain, should not hinder the acknowledgement (through the suggested ways or others) of the epistemic positivity of economic and political factors (Ágoas, 2017, p. 478). 
This paper, through a literature review, discusses sociological knowledge and sociology as scientific knowledge, as "the knowledge of the social world contributes to transforming it" (Tanguy, 2012, p. 34), as knowledge production in respect for ethics and social responsibility (Matas, 2018). This is carried out with full awareness of other stances that link Sociology, also, to intervention in the social (Butollo, 2017).

\section{Sociological Knowledge}

To a certain extent, to Science, "The best way to depict social reality is not photography, but painting, insofar as this is always the painter's impression of the object" (Bilhim, 2005, p. 83). This takes place because, and to some extent (Tanguy, 2012), as argued by Silva and Pinto (1986), "science is an intellectually constructed representation of reality" (p. 11).

Since social reality is the set of phenomena that are produced and reproduced in society, it is the real object addressed by the various social sciences that seek to know this reality. As Silva and Pinto (1986) maintain, each social science has a specific perspective on social reality that (i) creates its own theoretical issue; (ii) defines research problems in the context of that issue; and (iii) constructs sets of principles, theories, methodical strategies and critical results that function as models or guidelines for research - paradigms. Therefore, it is the processes of knowledge that name and qualify social reality at the very moment of analysis, it is the disciplines that instil dimensions of this reality when analysing it. Sociology advocates a relationship of interdependence and complementarity between social sciences, which is vital for understanding the complexity of social reality, although the boundaries between each of the social sciences are precarious and fluctuating because they envisage differently the same social reality.

The scientific legitimacy of sociological knowledge implies that "The explanations of phenomena are provided by theories, which are structured corpus of propositions enunciated in a rational way on the basis of axioms (unproven fundamental propositions), which in turn define a paradigm, that is, a "theoretical model of thought" that will guide the whole investigation and the theoretical reflection in a given domain" (Javeau, 1998, p. 6). In short, each science constructs a formal object that is not a faithful replication of reality, but rather its theoretically controlled (re)construction (Nunes, 2005; Paiva, 2014; Bourdieu, 2013; Bartolucci, 2017).

Specifically on sociological knowledge as science (Garcia, 2016), it deals, for example, with "converting objective probabilities into subjective expectations of the actors" (Silva, 1986, p. 35), naturalising decisions that result, to a great extent, from the conditions of existence, and "tend to transform what is destiny into a vocation" (p. 36).

As Javeau states in his proposal on the basic Axioms of Sociology (1998), man is a unique and invariable species in time; the social is external to the individual; social phenomena have a meaning that can be highlighted by the application of scientific methods. These axioms materialise in the following features of Sociology as a science (Javeau, 1998, pp. 64 and 65): Rejection of the "great systems" of explanation closed on themselves; It is not possible to predict the social future; Social transformation is a concept that differs from progress; Accepts the plurality of scientific approaches; Considers the primacy of deduction over induction; Aims at the establishment of comprehensive explanatory systems through sets of concepts as instruments of the understanding of the real.

In short, "empirical research cannot be carried out without simplification - theoretically and methodologically controlled - of the infinite complexity of social reality" (Costa, 1992, p. 35).

\section{Sociology as Scientific Knowledge}

In the analysis of Sociology as scientific knowledge, scientific practices take place in and within reality, and situations of dispute emerge:

In science it is therefore not enough to have new and creative ideas; a good dose of controversy is necessary for such deviant theories to survive in an environment that is hostile to change. Discovery also represents a process of social recognition (Christoffersen, Almeida, \& Lycurgo, 2009, p. 509) [emphasis added]. 
Science indicates two interdependent realities: a product and a system of production. What a given science is as a product, as a "body of knowledge and results", depends on what it is as a system of production, as a system of scientific knowledge-producing activities.

Thus, science, and, hence, also Sociology, are influenced by internal and external factors (Almeida, 1994; Bartolucci, 2017; Machado Júnior, Souza, Parisotto, \& Palmisano, 2016; HamatiAtaya, 2018; Au, 2018; Zuckerman, 2018; Tang, 2017; Jedlikowska, 2016; Christoffersen et al., 2009; Tanguy, 2012), requiring a "constant socio-epistemological vigilance" (Hamati-Ataya, 2018, p. 15).

Sociology, as scientific knowledge, consolidates as a reflexive science whose purpose is to critically analyse what it does at several levels (its possibilities, its limits, its procedures), to assess the conditions in which it does so, as well as the effects of its activity (Costa, 1992), given that Sociology studies and is part of society. The knowledge of Sociology is permanently assimilated by society, influencing it, in a "dynamic cyclicity" (Costa, 1992, p. 118), as a permanently unfinished enterprise (Miskolczi \& Király, 2016). Sociology not only studies society but is also part of society. Sociology has something quite specific in relation to other disciplinary-professional fields: a sharp sociological awareness of itself, a permanent sociological self-reflexivity about Sociology as a social practice and system of representations, stage of conflicts of interest and games of power, about the practice of Sociology as a socially conditioned scientific and professional activity, socially produced and always with social consequences (Costa, 1992).

The process of knowledge production in Sociology has already been analysed, with several perspectives on this topic (Zougris, 2018):

[...] frames contributing to the internal structuration of the sociological discipline is characterized by a procedural plurality that could be explained by a variety of theoretical niches and methodological styles that develop communities of scholars organized in diverse intellectual camps. Various approaches and explanations of social phenomena create knowledge frames that are subject to social conditioning on which, cultural production mechanisms are founded, established, and consolidated through a circuit of interactions of agents—via academic journals-within fields forming the communities of scholars (Zougris, 2018, pp. 7 and 8).

In this sense, and in line with Torres (2016), several challenges are posed to scientific knowledge. It is equated whether the knowledge produced by sciences, namely by social sciences, being provisional and rewritable, temporally and historically situated, could not be mobilised as a "starting point for the conduct of society". This questioning poses the epistemological need of articulating the conditions of reality with the theoretical creations, allowing to understand the "connection between the theorisation of reality and the reality of this theorisation". Another challenge stems from the fact that modern knowledge enables the paradox of the use of specialised knowledge, invoking the existence of particular realities that require specific explanations, while acknowledging the need to go beyond the specific to articulate this knowledge in broader considerations. However, considering the issue of atomised knowledge versus a universal pretension is the first step towards solving this paradox. But the self-observation of modernity supposes, as a phenomenon of worldwide proportions, a necessary universalisation of its selfanalysis. Sociology, as a science of modernity, emerges as a decisive tool for the attainment of this task, entailing a theory of the social that goes beyond the sociological description (Torres, 2016, pp. 119-120).

In the process and production of scientific knowledge, for example in the implications of professional connections in the peer-review assessment (Teplitskiy, Acuna, Elamrani-Raoult, Körding, \& Evans, 2018), and especially in the sociological one, it is important to stress the relevance of Sociology in the thinking of society, as well as for society to think of itself and in this process. Reflexivity is indeed relevant and central (Reed, 2016).

According to Bartolucci (2017), "We could hardly explain the processes of change if we did not understand beforehand the social structure that sustains science and the patterns of action that are reproduced systematically from it" (p. 33). Even for Sociology, "It must be taken as an object and use all the instruments of knowledge at its disposal to analyse and understand the social effects that are exerted on it and that can disturb the specific scientific logic of its functioning" (Bourdieu, 
2013, p. 27).

As an example on our part, the digital is unavoidable in Sociology, both in research and in its teaching (Oglensky, 2016; Ferreira \& Serpa, 2017; Santos \& Serpa, 2017; Serpa \& Ferreira, 2018).

According to Ferreira (2007), the starting point of any sociological research is composed of representations, which reflect how society thinks about its relationships with the objects that affect it. As advocated by Durkheim (1993), "To understand how society represents itself and the world that surrounds it, it is the nature of society, and not that of individuals, that we should consider. The symbols with which she thinks about itself change according to what it is" (p. 18). These representations refer to categories of thought, through which a given society builds and expresses its reality; these categories are not given a priori and are not universal in awareness, but are linked to social facts, transforming themselves into social facts that can be observed and interpreted. For example, the process of medicalisation of popular sanatoria may be understood as the expression of a discourses coalition, that is, the interaction of various discourses, conjugated in reinterpretative modalities of certain social realities and phenomena (Correia, 2005, p. 43).

That is, the products of human activity are understood as if they were "things": outside history and social relationships. Still according to Ferreira (2007), these are classification operations that are

[...] classifiers in the sense of class producers, adding the specific effect of naming to the objective approximation of similar conditions, they are themselves classified (and hence classifiers of those who formulate it), because they are always produced from stances that are determined in the social space; the dialectics that articulates stances, positioning and the results of positioning, objective division, division of the world and divided world, is the key to understanding the origin and contours of the various classes, of several natures, in which the various societies tend to differentiate. [...] And what is in dispute in these struggles is, above all, the imposition of the criteria and the monopoly of the exercise of classification (Silva, 1994, pp. 59-60).

Thus, "Legitimacy is a state, legitimation is a process" (Machado Júnior et al., 2016, p. 186), and scientific legitimacy is critical in scientific knowledge (Estrada, 2016).

\section{Conclusions}

Sociology assumes itself as a demystifying science of common knowledge shared in society, but that, in reality, is not correct (Elias, 2008; Vieira, 2004) and in the promotion of sociological imagination (Mills, 1959), given that "Sociology is about seeing with a new pair of eyes; unlearning and relearning much of what we take for granted about society" (Hjelm, 2013, p. 872).

It is important to highlight a sociological perspective centred on the theoretical plurality of Sociology that seeks to articulate macro-social dynamics with local processes, allowing to link subjective meanings with practices, and which focus on the articulations between systems and actors, between structures and practices, between the reality of social conditions of existence and the social construction of reality (Dubar, 2006; Sethuraju, Prew, Abdi, \& Pipkins, 2013; Morrison, 2017; Ferguson, 2016). The respect for this pluralism is shaped by a conception of social/individual relationships that excludes unilateral and dogmatic answers. Pluralism consists of respecting different sociological orientations and mobilising them according to the intelligibility they bring to a precise phenomenon (Berthelot, 1992, 2000).

However, the relevance ascribed to Sociology should not be limited to the fact that it is receptive to interdisciplinary relationships (Bögenhold, 2017; Serpa, Ferreira, \& Santos, 2017). with other sciences, whenever this proves to be heuristically fruitful (Au, 2018). In fact, the division of labour between disciplines depends either on "variable socio-institutional conditions", or on the fact that they are not theoretically-methodologically impermeable (Silva \& Pinto, 1986; Zuckerman, 2018), despite, very often, not being easy for Sociology to fully assume itself in this interdisciplinarity (Lyle, 2016). 


\section{References}

Ágoas, F. (2017). História das ideias, história das ciências humanas e sociologia do conhecimento [History of ideas, history of human sciences and sociology of knowledge]. História, Ciências, Saúde-Manguinhos, 24(2), 465-482. doi:10.1590/s0104-59702017000200009.

Almeida, J. F. de (Coord.) (1994). Introdução à Sociologia [Introduction to Sociology]. Lisboa: Universidade Aberta.

Au, A. (2018). Sociology and science: The making of a social scientific method. The American Sociologist, 49(1), 98-115. doi:10.1007/s12108-017-9348-y.

Bartolucci, J. (2017). La ciencia como problema sociológico [Science as a sociological problem]. Sociológica, 32(92), 9-40.

Berthelot, J. M. (1992). L'intelligence du social [The intelligence of the social]. Paris: PUF.

Berthelot, J. M. (2000). Os novos desafios epistemológicos da sociologia [The new epistemological challenges of sociology]. Sociol. Probl. Prát., 33, 111-131.

Bilhim, J. A. F. (2005). Teoria organizacional. Estruturas e pessoas [Organizational theory. Structures and persons]. Lisboa: Instituto Superior de Ciências Sociais e Políticas.

Bögenhold, D. (2017). The order of social sciences: Sociology in dialogue with neighbouring disciplines. The Journal of Philosophical Economics: Reflections on Economic and Social Issues, XI(1), $27-52$.

Bourdieu, P. (2013). Elogio da Sociologia: Discurso de aceitação da Medalha de Ouro do CNRS [In Praise of Sociology: acceptance speech for the Gold Medal of the CNRS]. Revista Brasileira de Ciências Sociais, 28(83), 25-31. https://doi.org/10.1590/s0102-69092013000300002.

Butollo, F. (2017). Sociology as science and action. Österreichische Zeitschrift Für Soziologie, 42(1), 91-94. doi:10.1007/s11614-017-0258-6.

Christoffersen, M. L., Almeida, W. O., \& Lycurgo, T. (2009). Sociology of science: Are knowledge production and the quest for scientific status two divergent courses? História, Ciências, Saúde-Manguinhos, 16(2), 505-513. doi:10.1590/s0104-59702009000200012.

Condorelli, R. (2018). Cultural differentiation and social integration in complex modern societies. Reflections on cultural diversity management strategies from a sociological point of view. Sociology Mind, 8, $249-303$. doi:10.4236/sm.2018.84019.

Correia, A. C. L. (2005). Na bancada do alquimista: As transformações curriculares dos ensinos primários e liceal em Portugal (1860-1960) [In the alchemist's bench: The curricular transformations of elementary and high school teaching in Portugal (1860-1960)]. PhD Thesis in Educational Sciences (History of Education). Faculdade de Psicologia e de Ciências da Educação, Universidade de Lisboa.

Costa, A. F. (1992). Sociologia [Sociology]. Lisboa: Difusão Cultural.

Dubar, C. (2006). Le pluralisme en sociologie: Fondements, limites, enjeu [Pluralism in sociology: Foundations, limits, stakes]. Socio-Logos, 1. Available at http://socio-logos.revues.org/20.

Elias, N. (2008). Introdução à Sociologia [Introduction to Sociology]. Lisboa: Edições 70.

Durkheim, E. (1993). As regras do método sociológico [The rules of sociological method] 5th ed. [1895] Lisboa: Editorial Presença.

Estrada, A. R. (2016). Tensiones teóricas en torno al estudio de la ciencia. De la sociología de la ciência al concepto de campo científico [Theoretical tensions around the study of science. From sociology of science to the concept of scientific field]. Andamios, 13(31), 13-36.

Ferguson, S.J. (2016). The center does hold: The sociological literacy framework. Teach. Sociol. 44, 163-176.

Ferreira, C. (2007). A medicalização dos sanatórios populares. Desafios e formas de um processo social [The medicalization of popular sanatoria. Challenges and forms of a social process]. PhD Thesis in Sociology. Lisboa: Faculdade de Ciências Sociais e Humanas, Universidade Nova de Lisboa.

Ferreira, C., \& Serpa, S. (2017). Challenges in the teaching of sociology in higher education. Contributions to a discussion. Societies, 7(4), 30. doi:10.3390/soc7040030.

Garcia, F. J. C. (2016). Ciencia, revolución y nacimiento de la sociología [Science, revolution and birth of sociology]. Civilizar Ciencias Sociales y Humanas, 17(33), 163-176. doi:10.22518/16578953.906.

Hamati-Ataya, I. (2018). The "vocation" redux: A post-Weberian perspective from the sociology of knowledge. Current Sociology, 001139211875647. doi:10.1177/0011392118756472.

Hjelm, T. (2013). Empowering discourse: Discourse analysis as method and practice in the sociology classroom. Teach. High. Educ., 18, 871-882. doi: 10.1080/13562517.2013.795940.

Javeau, C. (1998). Lições de Sociologia [Lessons of Sociology]. Oeiras: Celta Editora.

Jedlikowska, D. (2016). In searching for science understanding. Applying the sociology of a science based approach. Journal of Education Culture and Society, 7(2), 11-19. doi: 10.15503/jecs20162.11.19.

Kurawa, S. S. (2012). Social order in Sociology: Its reality and elusiveness. Sociology Mind, 02(01), 34-40. doi:10.4236/sm.2012.21004. 
Lyle, K. (2016). Shaping the future of Sociology: The challenge of interdisciplinarity beyond the Social Sciences. Sociology, 51(6), 1169-1185. doi:10.1177/0038038516653728.

Lellouche, S. (2009). As ciências sociais no tempo das redes [Social Sciences in the networks era]. In J.-F. Dortier (Dir.), Uma história das ciências humanas [An history of human sciences] (pp. 269-272). Lisboa: Edições Texto \& Grafia.

Machado Júnior, C., Souza, M. T. S., Parisotto, I. R. S., \& Palmisano, A. (2016). A contribuição da sociologia do conhecimento para os estudos de institucionalização e legitimação do conhecimento do campo científico [The contribution of the sociology of knowledge to the studies of knowledge institutionalisation and legitimation in the scientific field]. Organizações \& Sociedade, 23(77), 231-246. doi:10.1590/19849230773.

Matas, J. A. V. (2018). Values and science: An analysis the ethics in the science. Sociol Int J., 2(3), 257-265. doi: 10.15406/sij.2018.02.00056.

Mills, C. W. (1959). The sociological imagination. Oxford: Oxford University Press.

Miskolczi, P.; Király, G. (2016). Teaching society? Looking for new ways to teach Sociology in contemporary Hungary. Družboslovne Razpr. 32, 83, 63-81.

Morrison, A. (2017). A sociologist teaches history: Some epistemological and pedagogical reflections. Educ. Stud., 53, 233-246.

Nunes, A. S. (2005). Questões preliminares sobre as ciências sociais (13rd ed.) [Preliminary issues about the social sciences]. Barcarena: Editorial Presença.

Oglensky, B. (2016). Saving face in cyberspace: Transition to on-line teaching in a sociology program. Sociology and Anthropology, 4(10), 915-921. doi:10.13189/sa.2016.041007.

Paiva, A. (2014). Pensamento sociológico. Uma introdução didática às teorias clássicas [Sociological thought. A didactic introduction to classical theories]. Lisboa: PACTOR - Edições de Ciências Sociais, Forenses e da Educação.

Reed, I. A. (2016). Ethnography, theory, and sociology as a human science: An interlocution. Ethnography, 18(1), 107-129. doi:10.1177/1466138115592417.

Santos, A. I., \& Serpa, S. (2017). The importance of promoting digital literacy in higher education. International Journal of Social Science Studies, 5(6), 90. doi:10.11114/ijsss.v5i6.2330.

Serpa, S., \& Ferreira, C. (2018). Training models and practices in sociology. Societies, 8(3), 56. doi:10.3390/soc8030056.

Serpa, S., Ferreira, C. M., \& Santos, A. I. (2017). Fostering interdisciplinarity: Implications for social sciences. International Journal of Social Science Studies, 5(12), 44. doi:10.11114/ijsss.v5i12.2775.

Sethuraju, N., Prew, P., Abdi, A., \& Pipkins, M. (2013). The consequences of teaching critical sociology on course evaluations. SAGE Open, 1-15. doi: 10.1177/2158244013496182.

Silva, A. S., \& Pinto, J. M. (1986). Uma visão global sobre as ciências sociais [An overview of social sciences]. In A. S. Silva, \& M. Pinto (Eds.), Metodologia das Ciências Sociais, 8th ed. [Methodology of Social Sciences] (pp. 9-27). Porto: Edições Afrontamento.

Silva, A. S. (1986). A ruptura com o senso comum nas ciências sociais [The rupture with common sense in social sciences]. In A. S. Silva, \& M. Pinto (Eds.), Metodologia das ciências sociais, 8th ed. [Methodology of Social Sciences] (pp. 29-53). Porto: Edições Afrontamento.

Silva, A. S. (1994). Tempos cruzados. Um estudo interpretativo da cultura popular [Crossed Times. An Interpretative Study of Popular Culture]. Porto: Afrontamento.

Vieira, M. M. (2004). Converter incrédulos: A sociologia na cidade das ciências duras [Converting skeptics: Sociology in the city of hard sciences]. In C. M. Gonçalves, E. Rodrigues, \& N. Azevedo (Eds.), Sociologia no ensino superior: Conteúdos, práticas pedagógicas e investigação [Sociology in higher education: Contents, pedagogical practices and research]. Proceedings of the Meeting Sociologia no Ensino Superior: Conteúdos, Práticas Pedagógicas e Investigação [Sociology in Higher Education: Contents, Pedagogical Practices and Research]. School of Humanities of the University of Porto, Porto, Portugal, 67 December.

Tang, J. (2017). How do we know? What intelligence analysis can learn from the sociology of science. Intelligence and National Security, 32(5), 663-674. doi:10.1080/02684527.2017.1311473.

Tanguy, L. (2012). A sociologia: Ciência e ofício [Sociology: Science and craft]. Educ. Soc., 33(118), 33-46. Available at http://www.cedes.unicamp.br.

Teplitskiy, M., Acuna, D., Elamrani-Raoult, A., Körding, K., \& Evans, J. (2018). The sociology of scientific validity: How professional networks shape judgement in peer review. Research Policy, 47(9), 1825-1841. doi:10.1016/j.respol.2018.06.014.

Torres, F. (2016). Aproximaciones al conocimiento de lo social: Entre teoría social y sociologia [Approaches to the knowledge of the social: Between social theory and sociology]. Cinta de Moebio, 55, 106-120. doi:10.4067/s0717-554x2016000100008.

Zougris, K. (2018). Communities of scholars: A conceptual scheme of knowledge production. Societies, 8(4), 118. doi:10.3390/soc8040118. 
Zuckerman, H. (2018). The sociology of science and the Garfield effect: Happy accidents, unanticipated developments and unexploited potentials. Frontiers in Research Metrics and Analytics, 3. doi:10.3389/frma.2018.00020. 